\title{
Personal and Objective Ethics: How to Read the Crito
}

\author{
HIROSHI OHTANI
}

\begin{abstract}
Dominant interpretations of Plato's Crito attempt to reconstruct the text deductively, taking the arguments in the famous Laws' speech as consisting solely in the application of general principles to facts. It is thus conceived that the principles and facts are grasped independently of each other, and then the former are applied to the latter, subsequently reaching the conclusion that Socrates must not escape. Following the lead of Cora Diamond, who argues against this 'generalist interpretation', I argue that the Laws' speech essentially involves an exercise of our moral imagination through which both principles and the facts to which they apply are grasped. This is not to say that a deductive argument is absent from the Laws' speech. Rather, for the first time, we understand how the deductive arguments in the Laws' speech can function through imagining a life in which these arguments make sense. The Crito is an attempt to exercise the readers' imagination, thereby presenting ethics that is both personal and objective. Understanding the Laws' arguments essentially requires the readers' imaginative involvement with Socrates' personal story, but they still have objective import.
\end{abstract}

\section{Introduction}

Dominant interpretations of Plato's Crito attempt to reconstruct the text deductively, searching for the arguments that apply to states and their citizens generally in the famous Laws' speech. According to such 'generalist interpretations', ethics in the Crito consists solely in providing deductive arguments that reach the conclusion that Socrates must not escape. In this reading, readers are invited to reconstruct such arguments from the text.

In her article 'Missing the Adventure', Cora Diamond takes issue with this conventional interpretation. She asserts that in the Crito, Socrates engages in an exercise of moral imagination, trying to shift our perspective regarding his death. Diamond posits that Socrates is not offering a general deductive argument for his decision to stay in jail but instead urges his friends to see his death in a new light:

doi:10.1017/S0031819121000358 @ The Author(s), 2021. Published by Cambridge University Press on behalf of The Royal Institute of Philosophy. This is an Open Access article, distributed under the terms of the Creative Commons Attribution licence (https://creativecommons.org/licenses/by/4.0/), which permits unrestricted re-use, distribution, and reproduction in any medium, provided the original work is properly cited.

First published online 08 October 2021

Philosophy 972022 


\section{Hiroshi Ohtani}

[Socrates] enables his friends to read their way into his best possibility. His imaginative description of his situation, including the personification of the Laws, is an exercise of his moral creativity, his artistry. It is as much a significant moral doing as is his choosing to stay rather than to escape, or, rather, it in fact goes to any full characterization of what Socrates is doing in staying: the story of his death includes the imaginative understanding of the death by his friends, the understanding to which they are led by his remarkable description of the situation. (Diamond, 1991, p. 311)

According to Diamond, the point of the Crito is to understand Socrates' situation in a new way through moral imagination. We, the readers, and Crito, Socrates' interlocutor, begin with the belief that Socrates' obedient acceptance of his execution and unfair trial verdict is shameful to both his friends and himself and harmful to his children. After the dialogue, our view is changed, and we see that Socrates' decision to stay in jail is the most proper thing for him to do (Diamond, 1991, p. 312).

While Diamond's interpretation of the Crito, in my view, suggests a correct way to understand the text, it has been ignored by most Plato scholars. The dominant interpretation of the Crito remains the deductive approach. The reason for this neglect is, I suspect, twofold. First, Diamond is not a Plato scholar, and she does not cite other scholarship on Plato. Her critique of the generalist interpretation is directed toward William Frankena's argument in his ethics textbook, which is in no way intended as a contribution to Plato scholarship (Frankena, 1973). Second, Diamond does not offer a detailed analysis of the Crito. While her claims sound plausible, she does not explain in detail how her claims are supported by the text. Therefore, it is difficult to determine the validity of her reading.

In this paper, while I am inspired by Diamond's work, I attempt to offer a more rigorous reading of the Crito. The main contention of this paper is that the Crito's ethics does not consist solely of drawing a conclusion from the application of general principles to particular facts. Rather, the Crito is an attempt to exercise readers' imagination, thereby presenting ethics that is both personal and objective. I argue that while understanding arguments in the Crito essentially requires readers' involvement with the personal story of an individual, Socrates, ${ }^{1}$ they

1 When I say 'Socrates', I am referring to Socrates as portrayed in the Crito. The relationship between the historical Socrates and Socrates as a character in Plato's dialogues is beyond the scope of this paper. 


\section{Personal and Objective Ethics: How to Read the Crito}

still have objective import. Diamond's reading is essentially correct in rejecting the standard reading, which I call the 'generalist interpretation', according to which moral thinking as expressed in the Crito consists solely of the application of general principles to particular facts. I show both how an 'anti-generalist' interpretation inspired by Diamond's reading is supported by the text and how it contrasts with contemporary Plato scholarship on the Crito. The result is a stronger version of an anti-generalist interpretation and an extension of her insights into moral thinking.

The remainder of the paper is structured as follows: In the next two sections, I formulate the most adequate form of the generalist interpretation and argue that, even at its best, serious problems remain. Next, I offer my own interpretation, inspired by Diamond, and demonstrate how such an approach avoids the problems posed by the generalist interpretation. Finally, I demonstrate how my interpretation shows the Crito's ethics to be both essentially personal and with objective import.

\section{The generalist interpretation}

Although, following Diamond, I criticise the generalist interpretation, it should be noted that neither I nor Diamond claim that general principles have no significant role in Socrates' argument. On the contrary, it is undeniable that Socrates affirms some general principles before the Laws' speech, and they play a significant role in his argument. The first principle asserts that one must not do harm to others, even when one is harmed. This principle follows from two more fundamental ones: (1) one must never act unjustly, and (2) doing harm and acting unjustly are the same (Crito, 49a-49e). The second principle states that one must abide by a just agreement (Crito, 49e). After confirming these two general principles, Socrates then asks Crito whether his escape amounts to harming others and the breach of just agreement, and Crito exhibits perplexity:

Socrates: Then consider what follows: if we leave this place without first persuading the state, are we harming certain people and those whom we should do least harm to, or not? And do we stand by what we agreed to be just, or not?

Crito: I can't answer your question, Socrates, because I don't understand it. (Crito, $\left.49 \mathrm{e}-50 \mathrm{a}^{2}\right)$

2 In this paper, I use translations of Plato's works in Emlyn-Jones and Preddy (2017). 


\section{Hiroshi Ohtani}

Here, obviously, Socrates is asking whether his escape amounts to the violation of the two general principles he has just confirmed.

Neither Diamond nor I deny the importance of these general principles in Socrates' argument, although Diamond calls them 'themes', rather than 'principles' (Diamond, 1991, p. 312). ${ }^{3}$ What separates us from generalist interpreters is our understanding of the role the Laws' speech plays. The generalist interpretation takes the Laws' speech as providing deductive arguments, which are constituted only by the applications of general principles to facts. There, it is conceived that the principles and facts are grasped independently of each other, and then the former are applied to the latter, subsequently reaching the conclusion that Socrates must not escape. In contrast, the anti-generalist interpretation, which I will develop following Diamond's lead, holds that the Laws' speech essentially involves the exercise of our moral imagination, through which both principles and the facts to which they are applied are grasped. This is not to say that the deductive argument is absent from the Laws' speech. Rather, for the first time, we understand how the deductive arguments in the Laws' speech can function through imagining a life in which these arguments make sense. By hearing Socrates' life as the Laws tell it, we imagine a life in which the notions that appear in the deductive arguments make sense in the way that they can accomplish the roles they have in those arguments.

Now, before developing this line of interpretation, first let us examine the generalist interpretation. As already pointed out, it regards philosophical thought on ethics as consisting of the application of moral principles to facts to reach conclusions. As for the facts to which principles are applied, apart from epistemic problems, there is no philosophical problem. It may be the case that we have no warrant for some of our beliefs in these facts, but the problem here is epistemological rather than ethical. As Diamond says, according to the generalist interpretation, 'facts are facts; describe them' (Diamond, 1991, p. 311). A corollary of this characteristic of the

3 Hence, Socrates - as I presented him here - is not a moral particularist, if that means denying the significance of general principles altogether. Jonathan Dancy formulates particularism as the view that 'the possibility of moral thought and judgment does not depend on the provision of a suitable supply of moral principles' (Dancy, 2004, p. 7). This idea is not fully clear, but it indicates the denial of the view that every moral thought must be backed up by some general moral principles. If so, Socrates is a particularist in Dancy's sense. However, his formulation allows for various views on the role of moral principles within the particularist camp, some of which may be more aptly described as a form of generalism. 


\section{Personal and Objective Ethics: How to Read the Crito}

generalist interpretation is that it takes the Laws' arguments as citing the general relation between a state and its citizens, a relation which is grasped independently of Socrates' personal story included in the Laws' speech. Most - if not all - of the existing studies on the Crito agree with these two aspects. ${ }^{4}$

The next issue, then, is to determine the most persuasive version of the generalist interpretation. I contend that it draws on two main arguments in the Laws' speech: the respect argument and the argument from just agreements. The speech starts with the Laws' complaint that Socrates' escape will destroy both the city and the Laws:

Socrates: Well, look at it this way: if we were getting ready to abscond from here, or whatever you ought to call it, and the Laws and the community of the state were to come to me and standing over me were to ask: "Tell me, Socrates, what are you intending to do? By this action you're undertaking are you planning to do anything other than actually destroy us, the Laws, and the whole state in as far as it's in your power to do so? Or do you think that that state can continue to exist and not be overturned in which legal judgments have no force but are rendered invalid and destroyed by private individuals?" What shall we say, Crito, in reply to these and similar questions? (Crito, 50a-50b)

Some scholars take this passage as constituting an independent argument - the destruction argument - that Socrates' escape would violate the no-harm principle, and hence they think that there are three main arguments in the Laws' speech, rather than two (Brickhouse and Smith, 2004, pp. 213-14; Dasti, 2007, p. 131; Panagiotou, 1987, p. 38; Woozley, 1979, pp. 22-23, 62-63; Young, 1974, pp. 13-16).

However, I, along with Richard Kraut (1984, p. 52), interpret this passage as asking whether the destruction of the city and the Laws is morally justifiable. This passage does not aim to establish the unjustifiability of Socrates' escape. Rather, it first identifies his escape as amounting to the destruction of the city and the Laws, and then poses the question of whether it is morally justifiable. The Laws' answer to this question is not offered here, but in their subsequent arguments.

This interpretation is based on two pieces of evidence. First, the expression 'do harm (kakourgein)' does not appear in the passage. The Laws claim that Socrates' escape will destroy the city and the

4 See Allen (1980); Brickhouse and Smith (2004); Dasti (2007); EmlynJones and Preddy (2017, pp. 201-208); Kraut (1984); Panagiotou (1987); Wasmuth (2020); Woozley (1979). 


\section{Hiroshi Ohtani}

Laws (Crito, 50a-50b). Gary Young thinks that destruction and harming are equivalent here (1974, pp. 13-14; see also Brickhouse and Smith, 2004, p. 214). However, this view implies that Crito claims that 'doing harm to the city is justifiable when one is wronged' when he gives an affirmative answer to Socrates' question quoted above (Crito, 50c), yet this claim obviously violates the noharm principle and makes subsequent arguments unnecessary. Therefore, rather than presupposing the equivalence of destruction and harm, we must interpret the passage above as raising a question concerning the relationship between these two terms. Second, Socrates does believe that the destruction of a city is morally justifiable at times. He believes that one must serve in the military (Crito, $51 \mathrm{~b}-51 \mathrm{c})$, and he is proud of having served in battle himself (Apology, 28d-28e), which surely means he has, at some point, been involved in the attempted destruction of some city. While Socrates believes that attempting to destroy his mother city is morally unjustifiable, the belief is not derived from a general commitment against the destruction of any city.

These two points suggest that we should focus on two arguments, rather than three, when we formulate the generalist interpretation. The first argument is the respect argument, which is developed at $50 \mathrm{c}-51 \mathrm{c}$ of the Crito. There, the Laws first make Socrates agree that he finds no flaw in the laws concerning marriage, nurture, and education (Crito, 50d-50e). Then, the Laws argue as follows:

Well then, since you were born, brought up and trained, could you say in the first place that you were not both our offspring and slave: yourself as well as your ancestors? And if this is the case, do you think what is just applies equally to you and us, and whatever we try to do to you, do you think it's just for you to do back to us as well? Or is it the case, then, that when what is just did not apply equally to you in respect of your father and a slave master, if you happened to have one, so that whatever was done to you, you could not do back, and when you were told off you could not answer back, and when beaten you could not hit back, or any of the many other things of this kind; but yet it will be possible for you to be on equal terms with your fatherland and with its laws so that, if we think it's just and attempt to put you to death, will you on your part attempt in return to destroy us, the Laws, and your fatherland in so far as you can, and say that in doing this you're acting justly - you, the one who really cares for goodness? (Crito, 50e-51a) 


\section{Personal and Objective Ethics: How to Read the Crito}

The Laws' conclusion is that, if Socrates escapes, he fails to show due respect to the Laws (and the Athenian city; Crito 51a-51c). The interpretive point is to explain why the Laws think that Socrates' escape amounts to a failure to show them due respect, and the previous studies, qua generalist interpretations, try to specify the general relation between the Laws and their citizens that grounds their requirement for respect.

Scholars such as Gary Young and Verity Harte take the Laws' claim that Socrates is their offspring and slave at face value (Harte, 1999, p. 135; Young, 1974, p. 16). They argue that the Laws claim that they are Socrates' parents/master because they gave birth to, nurtured, and educated him.

However, the text does not require that we understand the parent/ master analogy so straightforwardly. First, as Harte herself points out (1999, p. 135), the Laws claim neither that they themselves gave birth to Socrates nor that they nurtured or educated him. They claim that, through them, Socrates' parents gave him life and brought him up (Crito, 50d). The Laws are claimed to have given the means and the instruction through which Socrates' parents gave birth to, nurtured, and educated him. Second, the Laws' overall point is that they deserve more respect than Socrates' parents:

Or are you so wise that you've failed to see that your native city is a thing of greater worth than your mother and father and all the rest of your ancestors, and more worthy of respect, holier and held in greater esteem both among the gods and men of good sense, and you should revere, defer to and humour your native city when it is angry sooner than your father...? (Crito, 51a-51b)

Here, the Laws, by rhetorically posing a question, do not stick to a literal identification of themselves as Socrates' parents. Rather, their contention is that they deserve his respect more than his parents do. The text does not require positing that the Laws are literally Socrates' parents. ${ }^{5}$

Thus, the more reasonable generalist interpretation should avoid the literal identification of the Laws as parents/masters. The standard view refers to the benefits the Laws confer to their citizen:

Perhaps it is better, then, to suppose that the Laws are claiming much the same status as a foster-parent or guardian, to whom the

$5 \quad$ Moreover, the idea of literally taking Socrates as the slave of the Laws is problematic because it is in tension with the text where the agreement between the Laws and Socrates is regarded as that between the Laws and Socrates as a citizen in contrast to a slave (Crito, $52 \mathrm{c}-52 \mathrm{~d})$. 


\section{Hiroshi Ohtani}

child owes some debt of gratitude for benefits received. (Bostock, 1990, p. 11)

The idea seems to be that just as an offspring owes his or her parents 'honor, respect, and reverence,' so the citizen owes these same things to the state, only the citizen owes the state more 'honor, respect, and reverence,' presumably because benefits the citizen receives from the state are greater than those a parent can bestow on children. We have a duty, in other words, to show the most proper respect to those who have provided us with the most important goods we enjoy. (Brickhouse and Smith, 2004, p. 216)

The idea, as clearly stated in these two quotations, is that because the Laws confer greater benefits to citizens than do their parents, they owe greater respect to the Laws. Accordingly, this general relation of the Laws' conferring benefits to their citizens grounds the latter's duty of respect to the former.

This is a natural and reasonable reading that evades the problematic literal acceptance of the parents/master analogy if we stick to the generalist interpretation. It is rendered a bit formally as follows:

(i) If someone, A, confers greater benefits to someone else, $\mathrm{B}$, in respect of B's life, nurture, and education than do B's parents, then A deserves B's respect more than do B's parents. (Crito, $50 \mathrm{c}-51 \mathrm{c})$

(ii) The Laws confer greater benefits to Socrates in respect of his life, nurture, and education than do Socrates' parents. (Crito, $50 \mathrm{~d}-\mathrm{e})$

(iii) Therefore, the Laws deserve Socrates' respect more than do Socrates' parents. ((i) and (ii); Crito, 51a-b)

(iv) If someone destroys, in retaliation, someone, $\mathrm{C}$, who deserves one's respect more than do one's parents, then one does harm to C. (Crito, 50e-51a)

(v) Therefore, if Socrates destroys the Laws in retaliation, then Socrates does harm to the Laws. ((iii) and (iv); Crito, 50e-51a)

(vi) Socrates' escape is equivalent to the destruction of the Laws. (Crito, 50a-50c)

(vii) Therefore, if Socrates escapes, then he does harm to the Laws. ((v) and (vi))

(viii) Therefore, Socrates must not escape, even though he is harmed by the Laws. ((vii) and the no-harm principle; Crito, 51b-51c) 


\section{Personal and Objective Ethics: How to Read the Crito}

Let us move on to the second argument, the argument from just agreements, stated as follows:

For, having given you birth, having brought you up and educated you, having shared all good things we' re capable of with you and the rest of your fellow citizens, we nevertheless proclaim that we've given permission to any Athenian who wishes it, if, when he has been scrutinized and sees the city in operation and us the Laws, he finds us unsatisfactory, to take his belongings and go anywhere he wishes. Moreover none of us laws stands in your way or forbids you, whether any of you wishes to go to colony, if both we and the city are displeasing, or go and emigrate somewhere else wherever he wishes with his property. But whoever of you stays behind, observing how we make legal decisions and administer the other aspects of city life, we say that this person has already agreed with us by his action to do whatever we bid him to do. (Crito, 51c-51e)

Here, the Laws contend that their citizens tacitly accept the agreement to obey their demands when some conditions are satisfied. These conditions are that (a) the Laws have 'shared all good things', that is, conferred the benefits to the citizens as far as they could; (b) citizens are not coerced to accept the agreement by being permitted to freely leave the city with their belongings when it is unsatisfactory for them; (c) the city is governed transparently, and citizens can observe 'how [the Laws] make legal decisions and administer the other aspects of city life'; (d) citizens are pleased with the city; and (e) the citizens apply for its citizenship. ${ }^{6}$

Now, we can render the argument from just agreements as follows:

(i) Consider the conditions (a)-(e) above.

If the laws of any city and its citizens pairwise fulfil conditions (a)-(e), then the citizen has agreed to obey (or persuade) the laws. (Crito, 51e-52a)

(ii) The Laws of Athens and Socrates pairwise fulfil conditions (a)-(e). (Crito, 52a-52d)

(iii) Therefore, Socrates has agreed to obey (or persuade) the Laws of Athens. ((i) and (ii))

(iv) Therefore, Socrates must obey (or persuade) the Laws of Athens. ((iii) and the principle of just agreement)

6 As Kraut and Brickhouse and Smith point out, the Laws refer to the Athenian process of gaining citizenship (dokimasia), in which a person should apply for citizenship (Brickhouse and Smith, 2004, pp. 217-18; Kraut, 1984, pp. 154-56). 


\section{Hiroshi Ohtani}

\section{The problems with the generalist interpretation}

Having formulated the Laws' two arguments in the generalist framework, I now claim that they have several problems. Consider the respect argument first: premise (ii) in the reconstruction above seems untrue. If we look for an argument that supports premise (ii) in the Crito, it is the Laws' claim that Socrates' maturity depends on Athenian laws concerning marriage, nurture, and education (Crito, 50c-50e). However, if this is the argument supporting premise (ii), it fails. Even granted that these laws confer benefits to Socrates, what they offered was the means and instructions through which his parents begat and brought him up, as the Laws themselves state. ${ }^{7}$ This means that these laws are merely background conditions for Socrates' maturity, and does not seem to establish the claim that the Laws confer greater benefits to Socrates than do his parents. The Laws might provide some benefits that Socrates' parents could not provide, such as the general safety in a lawful society. However, it is controversial, to say the least, that such benefits justify the claim that the Laws conferred greater benefits than Socrates' parents did. Additionally, it is not clear from the generalist conception of the respect argument why such strict obedience from citizens is required. If a father unjustly attempts to kill his child, is it not permissible for the child to escape even though its escape would hurt the father (see Bostock, 1990, p. 11)?

The problem here is that the notion of benefit, as conceived in a normal, mundane way, ${ }^{8}$ does not seem to justify the Laws' claim for greater respect than parents/masters, nor does it imply that Socrates owes such strict respect to them that it prohibits him from escaping when he has seriously done wrong. It is not clear why the benefit of aiding the birth and maturity of Socrates should result in such a strict duty of respect, as far as we imagine the life of a citizen in a law-governing, democratic state.

A similar problem can be raised for the generalist conception of the argument from just agreements. The Laws contend that the

7 Crito too thinks that parents have responsibility for their children's maturity, and he never mentions the Laws' role in it $(C r i t o, 45 \mathrm{c}-45 \mathrm{~d}$. Cf. Harte, 1999, p. 135).

8 Stating that a notion or concept is conceived in a normal, mundane way, I am referring to the conception which is related to the general consideration regarding the status of a citizen in a law-governing, democratic state. To grasp the conception, we are required to imagine the ordinary course of a citizen in a democratic society such as Athens, in contrast to the life of Socrates, the philosopher for Athens. 


\section{Personal and Objective Ethics: How to Read the Crito}

agreement between them and Socrates is very strict, forbidding Socrates to escape even when there is an unjust attempt to kill him. However, as the alleged agreement is tacit, made by his action (Crito, 51e), its precise content is unclear. Therefore, it is puzzling why such a strict agreement is implied by the fact that Socrates and the Laws pairwise fulfil the conditions stated in the argument from just agreements.

The problem is that, whatever the conditions extracted from the Crito's text, we cannot understand why the content of the agreement is so strict given our understanding of the notion of agreement in the normal way. That is, we cannot see why the agreement is so strict if we think only about the agreement required for a citizen. Given that Socrates' verdict is unfair, it seems to us that the conditions of the agreement are already undermined. We cannot understand why Socrates must stick to the agreement on pain of being killed as a result of an unfair verdict.

The criticisms of the generalist conceptions of the respect argument and the argument from just agreements are both directed towards the generalist supposition that moral principles are graspable independently of the descriptions of the fact that Socrates fulfils the conditions for the duty of respect or agreement. Under this supposition, we cannot but understand the notion of benefits or that of agreement without reference to Socrates' specific way of living. Thus, we cannot comprehend these notions except in the normal, mundane way. As a result, it becomes unclear why so strict a duty and agreement are implied by the fact that Socrates fulfils the conditions rendered by the Laws.

At this point, one may object that we can understand Socrates' duty and agreement by some general considerations. For example, it might be argued that Socrates' escape amounts to publicly announcing that a person who has a rich friend can evade the court's verdict by means of bribery, hence destroying the civic trust that is necessary for a democratic society, such that Socrates has a duty to, and is in agreement with, accepting the verdict (Gowder, 2015). This is a consideration of the general duty and agreement of a citizen in a democratic society rather than on a particular duty or agreement tailored specifically for Socrates. Or, more simply, it might be argued that citizens in a law-governing state must obey the verdict of the court even when they think it misguided (Allen, 1980, pp. 94-96; Panagiotou, 1987, pp. 40-42; Wasmuth, 2020, pp. 398-99). That is, they must respect every verdict regardless of their own opinions about whether the accused are really guilty of the crimes they are accused of. For, if citizens are required to obey a verdict only when they think it faithful to 


\section{Hiroshi Ohtani}

the relevant facts, the idea of the court's verdict becomes almost void. Again, this is a general consideration concerning the duty and agreement of citizens in a law-governing state. Therefore, according to the objection, we can perfectly understand the duty and agreement of Socrates, who lived in a lawful democratic state, by the general consideration of citizens' duties and agreements.

To this objection, I respond by making two points. First, such general considerations cannot explain Socrates' strict duty and agreement because his verdict is the result of an unfair trial. The problem of the trial consists not just in the jury failing to render a correct verdict, but many of them fail to investigate the truth of the charge, which is their duty (Apology, 18a, 38c-39b). The failure here is not epistemic but lies in many of the jury having neglected their duty. Granted that citizens of a law-governing democratic state have the duty and agreement to accept a verdict even when they do not think it correct, it does not follow that they must accept the verdict resulting from an unfair trial.

Second, Socrates sets these general considerations aside. Just after introducing the Laws, he imagines a case in which a public advocate ${ }^{9}$ defends the law that the court's judgements are sovereign:

You see someone, especially a public advocate, would have plenty to say about the violation of this law that directs that judgments, once pronounced, are sovereign. Or shall we say in response to them that yes, the state has behaved unjustly toward us because it has not given the right verdict in this case'. Shall we say this, or what?

Crito: We shall, by Zeus, Socrates. (Crito, 50b-50c)

Here, Socrates thinks that the general considerations that would be provided for the existence of a citizen's duty will not convince Crito and is not what is at issue. However, considerations cited in the objections above would be included in such general considerations. We can easily imagine that a public advocate claims that citizens must accept every verdict, including the ones they consider misguided. Therefore, we should take this passage as raising the issue of whether there is any reason for Socrates to stay, even when he is seriously wronged. ${ }^{10}$ Even though we accept that there is some

9 In Athens, public advocates were appointed to defend the laws which were proposed for abolishment (Burnet, 1924, p. 281).

10 I read the passage differently from Ellisif Wasmuth, who claims that Socrates' putative answer is that the case was not judged correctly (2020, pp. 398-99). Wasmuth's argument is ingenious, and I cannot make a 


\section{Personal and Objective Ethics: How to Read the Crito}

consideration which explains the duty and agreement to obey the court's verdict in general, such consideration is not considered to explain the duty and agreement of Socrates in particular and is not cited in the Laws' speech that follows. Therefore, I conclude that the generalist interpretation cannot explain the strict duty and agreement to which Socrates is claimed to be committed. ${ }^{11}$

These objections to the generalist conception of the Laws' arguments amount to the claim that it makes the Laws' arguments too weak. It is not that the conception squarely contradicts the text. However, if there is another interpretation that makes more sense or is more strongly defensible, then that interpretation would be preferable. ${ }^{12}$

\section{Socrates' personal story and an anti-generalist reconstruction of the Laws' speech}

In this section, I present an alternative reading of the Laws' speech. I begin with the argument from just agreements. I contend that the existence of the strict agreement between the Laws and Socrates claimed in the argument becomes understandable only through exercising our moral imagination.

detailed examination of it here, but just offer one point in response: the view that the failure of Socrates' verdict consists in its giving the incorrect result is not Socrates' view in the Apology, in which he refuses to call the jury who voted for guilty 'members of jury' (Apology, 39e-40a).

11 Does Socrates really accept the claim that he is seriously wronged by the state? My answer is that the Laws' two main arguments are developed under the supposition that the claim is correct. Earlier in the dialogue, Socrates refers to the principle that 'we mustn't retaliate if we are treated unjustly' (Crito, 49b). If he does not suppose that the claims are correct, this reference to the prohibition of retaliation would be puzzling. Therefore, the Laws' two arguments are made under that supposition, one that is unfavourable to them, though, later, after concluding that Socrates' escape would be unjust, the Laws seem to retreat from the supposition (Crito, $54 \mathrm{~b}-54 \mathrm{c})$.

12 Some scholars, partly because they acknowledge the weakness of the Laws' argument, contend that the Laws' speech cannot be ascribed to Socrates (Brown, 1992; Harte, 1999; Moore, 2011; Weinrib, 1982; Weiss, 2001; Young, 1974). They argue that the Laws' speech is a kind of rhetoric, unsupported by reason, that leads Crito to the correct conclusion while Socrates himself does not endorse it. This interpretation, however, is problematic; it makes Socrates a kind of cheat who relies on oratory to make his point, an approach he despises (see Gorgias). 


\section{Hiroshi Ohtani}

To see how the alternative anti-generalist reading is possible, let us first see the Laws' explanation of how Socrates fulfils the conditions for the agreement, in which we find that Socrates' personal story is told. The Laws say that Socrates has stayed in Athens for his entire life, except for his military service, that he has children in the city, that he does not propose exile as his punishment at trial, and that he praises other cities like Sparta and Crete for being well governed (Crito, 52b-53a). Based on this detailed biography of Socrates, the Laws argue that he has agreed to obey them.

We can ask here why such a detailed story is necessary. ${ }^{13}$ Why do we need Socrates' personal story, unique to him? Under the generalist interpretation, the answer is that the story demonstrates that Socrates fulfils the general conditions of agreement. For example, Kraut argues that Socrates' personal story is told because it shows his satisfaction with the city, which is supposed to constitute a crucial step in his agreement to obey the Laws. Kraut's view is not that Socrates' subjective psychological state of being satisfied constitutes his agreement (1984, pp. 174-75) - this would make the notion of agreement nearly empty. Rather, Kraut suggests that expression of satisfaction can constitute agreement. According to him, Socrates' personal story is told because there is no fixed list of behaviours that express satisfaction. For example, if, when asked to take a trip to the mountains, one smiles, offers kisses, and begins to pack one's bags, this demonstrates satisfaction, which constitutes implicit agreement to take the trip. According to Kraut, the Laws think in a similar way: Socrates' personal behaviours express his satisfaction with the city, which constitutes his agreement to obey the Laws (Kraut, 1984, pp. 172-74).

Alternatively, a generalist reader may argue that the Laws overdetermine the case for condition (d) of the argument from just agreements. According to this reading, the Laws argue that there is plenty of evidence indicating that Socrates fulfils condition (d) of the argument from just agreements, although just referring to the fact that Socrates remained in the city might be sufficient for that.

Whatever the merits of these explanations, they carry over the problem I raised for the generalist interpretation in the previous section. If we think that the point of Socrates' personal story being told consists in showing that he fulfils some general condition for agreement, it is not clear why the fact that he fulfils it and the other conditions imply the strict agreement that prevents him from

13 Gregory Vlastos finds this part of the Laws' speech problematic and contends that it should be excised from the Crito (1974, pp. 523-27). However, I believe we should look for a more charitable reading. 


\section{Personal and Objective Ethics: How to Read the Crito}

escaping. The problem is that even if the Laws' argument shows that the general conditions of the agreement are fulfilled and thus that an agreement exists between them and Socrates, we can ask whether the agreement in question still holds when Socrates is seriously wronged. This problem does not disappear even when we suppose that the agreement is established in a non-conventional way or by overdetermining the case. The problem is not regarding how agreement is established, but what the content is.

Moreover, it is also puzzling under the generalist interpretation that the Laws argue that Socrates is 'among the most culpable' (Crito, 52a) if he escapes. If what they argue is merely that Socrates satisfies some general conditions for the agreement, then what is at issue is whether he agreed or not. The talk of 'the most' here does not make sense under the generalist interpretation.

In contrast to the generalist interpretation, I do not take Socrates' personal story told in the Laws' speech as just showing that he satisfies some general conditions for agreement. On my alternative reading of Socrates' personal story, it is intended to exercise our moral imagination. Socrates' story is the story of his having decisively chosen Athens. Consider, for example, the Laws' reference to the fact that Socrates does not propose exile as punishment in his trial:

And again in the actual trial it was still possible for you to be sentenced to exile, if you had so wished, and to have done then with the city's consent what you are now planning to do against its will. But at the time you made a fine display of not objecting if you had to be put to death, but, as you said, you chose death rather than exile; yet now you show no shame for those words, nor do you pay heed to us the Laws in your attempts to destroy us. In fact you're doing what the most cowardly slave would do in attempting to abscond contrary to the articles and agreements according to which you agreed to conduct your life as a citizen. (Crito, 52c-52d)

If we take this passage as describing a general condition, we are misguided because Socrates' reason for not proposing exile is highly specific to him. In the Apology, he explains his reason as follows:

I would have to have a desperate love of life, my fellow Athenians, if I'm so irrational as not to be able to work out that you who are my fellow citizens have become unable to put up with my discourses and arguments, and they have become so irksome and hateful that you're now seeking to get rid of them. Will others in that case put up with them easily? Far from it, fellow Athenians. (Apology, 37c-37d) 


\section{Hiroshi Ohtani}

According to Socrates, his doing philosophy, which he believes to be his particular mission given to him by the god (Apology, 28c-29d), would lead to an unpleasant result for him because people in foreign cities would find it objectionable just as people in Athens did, so proposing exile was not a rational choice for him. This reason is specific to Socrates, to whom the mission of philosophising was given. Therefore, we can only understand the meaning of his not proposing exile during the trial by considering it as a part of the story about Socrates' specific way of choosing Athens.

The point is that Socrates' story is not something that shows his fulfilling the general conditions for agreement, conditions grasped independently of his personal story. Rather, we come to understand that the notion of agreement can be given content, which implies the strict requirement for obedience, through the story. As I have argued, the notion of agreement conceived in the ordinary way does not seem to imply strict obedience. The agreement made by a citizen in a law-governing, democratic state does not seem to be so strict. However, we are pressed to understand that there is a way of making such a strict agreement by seeing Socrates' way of decisively choosing Athens.

This is possible through moral imagination. Before reading the Laws' speech, it is unclear whether talking about agreement will help us understand Socrates' situation, as reflected by Crito's perplexity quoted in Section 2 of this paper (Crito, 50a; cf. Diamond, 1991, p. 311). However, after reading the speech, we come to see that Socrates has agreed to obey the Laws even when he is wronged by the city. In reading the Crito, we are not just required to apply the concept to Socrates in the ordinary way. Rather, we are urged to imagine a life in which the concept is given a renewed understanding. ${ }^{14}$

It follows that the problem I pointed out with the generalist interpretation of the argument from just agreements does not arise from my reading. This problem relates to it being unclear, under the

14 The Laws do not explicitly mention the divine mission. In my reading, this is because Plato prompts his readers to consider it themselves. We are expected to deliberate on what aspect of Socrates is to be relevant in order for the Laws' arguments to work. Note that here and in my reading of the argument from just agreements I presuppose that Plato thinks that his readers are familiar with the Apology, which presupposition is reasonable, given that there is a scholarly agreement that the composition of the Apology precedes that of the Crito (See Emlyn-Jones and Preddy, 2017, p. 213 , note 24 ). 


\section{Personal and Objective Ethics: How to Read the Crito}

generalist interpretation, why the agreement between the Laws and Socrates is so strict as to prevent him from escaping. On the other hand, in my reading, it is clear. The agreement between them is strict because they have come to a strict agreement, which we come to understand by imagining Socrates' personal story of the way he has decisively chosen Athens. Moreover, there is nothing puzzling about Socrates' personal story being told. It is an essential part of the argument from just agreements. The story presses us to imagine a life in which the strict agreement makes sense, thus making us see that the argument from just agreements works.

Here, one may object that when the Laws describe conditions for the agreement, they are presented in general terms (Crito, 51d-52a). In particular, the Laws say, 'Whoever of you stays behind, observing how we make legal decisions and administer the other aspects of city life, we say that this person has already agreed with us by his action to do whatever we bid him to do' $(C r i t o, 51 \mathrm{e})$. Therefore, the objection goes, it is not the case that the argument discussed by the Laws is something especially tailored for Socrates, but the argument cites just the general relation between a state and its citizens.

To this objection, I reply that, even though the conditions for the agreement are presented in general terms, that does not mean that they are understandable without reference to Socrates' personal story. The first thing to note is that when the Laws present the conditions for agreement, it is unclear how they are to be conceived. For example, even if we accept that 'whoever of you stays behind, observing how we make legal decisions and administer the other aspects of city life, we say that this person has already agreed with us by his action to do whatever we bid him to do', we cannot see why the agreement is still valid when a citizen is seriously wronged, as I discussed when criticising the generalist interpretation. Then, we should take the Laws' presentation of the conditions for agreement, especially the assertion that anyone who stays in the city has agreed to obey them, as being provided with an unclear conception and subsequently being clarified by Socrates' personal story. We can provide the determinate content for the assertion for the first time when we are told the story of Socrates having decisively chosen Athens. Therefore, we need not think that the fact that the conditions for agreement are described in the general terms implies that they are presented by citing only the general relation between a state and its citizen. ${ }^{15}$

15 Here, we can note that the Laws' arguments have a similar, though not the same, structure as Socrates' argument in the Apology 20e-23c, 


\section{Hiroshi Ohtani}

The respect argument can be read in a similar way as the argument from just agreements. I claim that the notion of benefits as described in it can be grasped only through understanding Socrates' special bond with Athens, which is told in his story and endorsed by Socrates in his exchange with the Laws. He endorses laws concerning his birth, nurture, and education, thereby approving his special bond with the city $($ Crito, $50 \mathrm{~d}-50 \mathrm{e})$. This bond holds not because Socrates happens to fulfil some general conditions, but because he personally honours it. The point is that the hierarchical relationship between Socrates and the Laws is not justified by citing the ordinary conception of 'benefits', but by Socrates' personal endorsement of his special debt to the Laws. If the respect argument merely refers to the existence of some laws as a condition of its citizens' maturity, we cannot see why the Laws deserve more respect than a citizen's parents, who are also responsible for that person's maturity. However, in my reading, the respect argument depends on Socrates' personal honouring of his special bond with the city and the Laws, the bond that is constituted by the fact that he was given to the city by the god as a philosopher, and that he spent his entire life engaged in philosophical activity (Apology, 30d-31c), the ability for which is enabled at least partly by the laws concerning his maturity. Here again, by imaginatively engaging with Socrates' personal story as told by the Laws, we come to see that the city of Athens and the Laws are more than background conditions of his maturity. The city is exactly the one to which he was dispatched as a philosopher by the god, and the Laws have enabled his philosophical activities. ${ }^{16}$ The bond between Socrates and the city and the Laws is not just between Socrates qua a citizen and them, but between Socrates qua the philosopher for Athens and them, which relationship is more worthy of respect than that between Socrates and his parents. For, being the philosopher for Athens constitutes his most important aspect.

where he is first perplexed by the oracle that no one is wiser than him and subsequently comes to understand what it means by examining it. There, the notion of being wise is first unclearly presented and then clarified.

16 Note that I do not claim that the Laws contribute to Socrates' maturity more than his parents as a matter of fact. Rather, my point is that Socrates himself honours the hierarchical relationship and the significance of his honouring it is understood only through his personal story, a part of which is constituted by the Laws' contribution to his maturity. 


\section{Personal and Objective Ethics: How to Read the Crito}

Some think that the respect argument reflects Socrates' authoritarian view of the relation between a state and its citizens (Hanna, 2007; Smith, 2014). According to this interpretation, Socrates thinks that the relation between a state and its citizens is essentially asymmetric: a state has a right to exercise power over its citizens even when the latter find it unjust, but not vice versa.

It is true that Socrates takes his relationship with the Athenian city as being asymmetric. In the passage that constitutes the respect argument, which I cited in Section 2 above, by posing a series of rhetorical questions, the Laws claim that their relationship with Socrates is hierarchical (Crito, 50e-51a). They think that Socrates must respect the Laws and the city, but not vice versa. However, in my reading, this hierarchical relation depends, at its root, on Socrates' personal honouring of the relationship. That is why the Laws ask for his endorsement when they establish their parent-like relationship with him (Crito, 50d-50e). Socrates' special bond with Athens, told in his personal story and endorsed by him, grounds the asymmetric relationship between the two.

Here again, we can see that the readers of the Crito are urged to exercise moral imagination. Before reading the Laws' speech, we do not even come up with the idea that Socrates owes special respect to the Laws and to Athens. Thus, Crito first affirms that it is permissible for Socrates to try to destroy the Laws when they wronged him (Crito, 50b-50c). However, by reading the Laws' speech, we are urged to imagine Socrates' way of living in which 'the benefits' he receives ground the special bond between him and the Laws. By imagining Socrates' life, we come to grasp the notion of benefits in a renewed way that makes his special due respect to the Laws understandable. ${ }^{17}$

Now, we can recapitulate the contrast between the generalist interpretation and my anti-generalist interpretation. According to the generalist interpretation, in each of the two arguments, the Laws first specify the general relation between the laws and their citizens

Harte (1999) persuasively cites evidence for the fact that the rhetoric of a city as the parent of citizens is pervasive in ancient Greek literature, and hence that Socrates and Plato are familiar with it. That said, Harte's argument does not refute my assertion - its point is not that that rhetoric is unfamiliar, but that we are made to see that it is relevant in Socrates' case by exercising our moral imagination. This point is supported by the fact that Crito, who is also familiar with that rhetoric, at first does not understand its relevance for grasping Socrates' situation (Crito, 50a), but comes to endorse it through hearing the Laws' speech (Crito, 51c). 


\section{Hiroshi Ohtani}

that grounds the latter's duty of respect or the agreement between the two, and they next show that Socrates and the Laws pairwise fulfil that general relation. Under this reading, understanding the general relation and seeing that the relationship between Socrates and the Laws reflected in that relation are considered to be two different steps independently described in the Laws' speech. In particular, Socrates' personal story or his endorsement of his bond with the Laws is taken merely as an element of the latter step. However, this feature of the generalist interpretation has the problem that it lacks the resources to make sense of the idea that the notion of benefits or conditions of agreement generates the very strict duty of respect or agreement that prohibits Socrates from escaping. As a result, the Laws' arguments seem too weak.

On the other hand, under the anti-generalist interpretation, Socrates' personal story and his endorsement of his special bond with Athens provide resources for making sense of his strict duty and agreement. Socrates' story and endorsement help us understand both the conditions for the duty of respect or agreement and that Socrates and the Laws fulfil those conditions. The Laws' speech is intended to urge us to imagine a life in which strict duty to respect and agreement do make sense.

Note that I am not claiming that deductive argument is lacking in the Laws' speech. When I emphasise the role of moral imagination, I do not claim that Socrates is so special that he is outside the scope of any deductive argument. My point is that by imagining Socrates' life, we can find the workable contents of the notions of benefits and agreement through which the Laws' deductive arguments could work. If we grasp these notions by citing the benefits conferred to, and agreement made by, a citizen of a law-governing, democratic state, the deductive arguments do not work. In contrast, by imagining Socrates' life as the philosopher for Athens, we come to understand the notions of benefits and agreement in a way that results in his strict duty to obey the verdict and, hence, the deductive arguments in the Laws' speech, can work.

\section{Personal and objective ethics}

If my anti-generalist interpretation of the Crito is correct, it should demonstrate that the ethics expressed in it is personal, yet still objective. The Crito's ethics is personal because we can understand the Laws' arguments only through Socrates' personal story. As for the respect argument, the notion of benefits therein is grasped only 


\section{Personal and Objective Ethics: How to Read the Crito}

through his personal story and endorsement of his special bond with Athens. Similarly, the conditions of agreement in the argument from just agreements are to be understood only through his personal story. ${ }^{18}$

At the same time, ethics in the Crito is objective. The Laws' two arguments are not arbitrary, but there is right or wrong here. We can ask whether the moral imagination exercised in Socrates' personal story is biased, based on the wrong information, and so on. Furthermore, we can check whether the conclusion coheres with other commitments he accepts.

Moreover, we can learn from the Laws' arguments. It is true that Socrates' life was unique. He is supposedly the only philosopher who was attached to Athens by the god (Apology, 30d-31a). However, that does not mean that we have nothing to learn from the Laws' arguments. We can compare the similarity and dissimilarity of our own lives to that of Socrates and thereby be urged to examine our own relationship with laws and the state to which we ourselves belong.

I suspect that the generalist interpretation is pushed forward by missing this conceptual space of personal and objective ethics. For example, R. E. Allen, criticising the kind of interpretation that sees the Crito as a mere record of the beauty of Socrates' personality, says:

[Socrates] chose to die rather than escape because he was convinced by reasoning that it was right to die and wrong to escape; and that reasoning is brought to conclusion in the speech of the Laws of Athens. Any account of the Crito which stresses the beauty of the man to the neglect of his argument may justly be suspected of missing the beauty of the man. (Allen, 1980, p. 83)

18 We can make the point explicit by adapting the second line of premise (i) of the argument from just agreement to (i)': 'If the laws of any city and its citizens pairwise fulfil conditions (a)-(e) in the way Socrates does, then the citizen has agreed to obey (or persuade) the laws'.

In saying this, I depart from the tradition that requires that the ethical principles must be free from proper names (Hare, 1981, p. 41; Rawls, 1999, pp. 113-14; Scanlon, 1998, pp. 209-213). The reason for this requirement is that, as T. M. Scanlon claims, we should not arbitrarily favour or disfavour particular persons or groups referred to by proper names in ethical thinking (Scanlon, 1998, pp. 211-13). However, the references to Socrates in my formulation of the Laws' arguments are not arbitrary, but supported by the personal story told in their speech. 


\section{Hiroshi Ohtani}

I agree with Allen that the point of the Crito lies in Socrates' reasoning. However, Allen does not see Socrates' personal story as a part of his reasoning. He presupposes that the reference to Socrates' personal story cannot have a significant role in ethical reasoning.

This presupposition is unfounded, as described above. The generalist interpretation depends on the narrow conception of reasoning, which ignores the possibility of personal and objective ethics. However, the fact that the Crito is full of personal stories about Socrates means that the generalist interpretation should not be the default choice. We should not suppose that the ethically relevant features of Socrates' situation are grasped apart from his personal story. If we so suppose, the generalist interpretation is the first choice. However, if we reject the supposition and allow that the ethically relevant features of his situation might be highly situation-specific and graspable only by imagining Socrates' life, then the anti-generalist interpretation makes more sense than the generalist because it has several advantages.

\section{Conclusion}

This paper demonstrates that the generalist interpretation of the Crito, although dominant in contemporary Plato studies, has numerous problems. The generalist interpretation takes the Crito's ethics as consisting solely in applying moral principles to facts and, therefore, takes the Laws' arguments as citing the general relation between a state and its citizens, which is grasped independently of Socrates' personal story as included in the Laws' speech. Under the generalist interpretation, the conditions for respect or agreement are grasped independently of the fact that Socrates fulfils them. The result is a peculiarly weak set of arguments. We cannot see why his fulfilling those conditions yields the strict duty for respect or strict agreement that prohibits him from escaping when he is seriously wronged.

In contrast, the anti-generalist interpretation I developed is free from such problems. It takes Socrates' endorsement of his special bond with Athens and his personal story told in the Laws' speech as the keys to understanding the Laws' arguments. According to my interpretation, we come to understand the Laws' arguments, which initially resist clear comprehension, through our moral imagination. The Crito is an attempt to exercise the readers' moral imagination, thereby presenting ethics that is both personal and objective. The Laws' arguments are comprehended only by imagining Socrates' personal life, but they still have objective import. 


\section{Personal and Objective Ethics: How to Read the Crito}

This paper's interest does not solely lie in its contribution to Plato scholarship. It demonstrates how ethics that essentially relies on moral imagination can proceed. Therefore, it opens up the possibility for ethics that is different from that which seeks a general deductive argument, to which the mainstream analytic philosophers aspire. ${ }^{19}$

\section{References}

R. E. Allen, Socrates and Legal Obligation (Minneapolis: University of Minnesota Press, 1980).

David Bostock, 'The interpretation of Plato's Crito', Phronesis, 35 (1990), $1-20$.

Thomas C. Brickhouse and Nicholas D. Smith, Routledge Philosophy Guidebook to Plato and the Trial of Socrates (New York: Routledge, 2004).

Hunter Brown, 'The structure of Plato's Crito', Aperion, 25 (1992), 67-82. John Burnet, Plato: Euthyphro, Apology of Socrates, Crito (Oxford: Clarendon Press, 1924).

Jonathan Dancy, Ethics without Principles (Oxford: Oxford University Press, 2004).

Matthew R. Dasti, 'The Crito's integrity', Aperion 40 (2007), 123-40.

Cora Diamond, 'Missing the adventure: Reply to Martha Nussbaum'. In C. Diamond, The Realistic Spirit: Wittgenstein, Philosophy, and the Mind, (Cambridge, Massachusetts: MIT Press, 1991) 309-18.

Chris Emlyn-Jones and William Preddy, Plato: Euthyphro, Apology, Crito, Phaedo (Cambridge, Massachusetts: Harvard University Press, 2017).

William K. Frankena, Ethics, Second edition (Englewood Cliffs, New Jersey: Prentice-Hall, 1973).

Paul Gowder, 'What the Laws demands of Socrates - and of Us', The Monist, 98 (2015), 360-74.

Nathan Hanna, 'Socrates and superiority', The Southern fournal of Philosophy, 45 (2007), 251-68.

R. M. Hare, Moral Thinking, (Oxford: Oxford University Press, 1981).

Verity Harte, 'Conflicting values in Plato's Crito', Archiv für Geschichte der Philosophie, 81 (1999), 117-47.

Richard Kraut, Socrates and the State (Princeton, New Jersey: Princeton University Press, 1984).

Christopher Moore, 'Socratic persuasion in the Crito', British Fournal for the History of Philosophy, 19 (2011), 1021-1046.

19 I presented an earlier version of this paper at Tokyo Forum for Analytic Philosophy (April, 2019, The University of Tokyo). Also, I benefited from discussion with Shigaku Nogami regarding an earlier version of this paper. 


\section{Hiroshi Ohtani}

Spiro Panagiotou, 'Justified disobedience in the Crito?', in Spiro Panagiotou, ed., Justice, Law and Method in Plato and Aristotle (Edmonton, Alberta: Academic Printing and Publishing, 1987) 35-50.

John Rawls, A Theory of Fustice, revised edition (Cambridge, Massachusetts: Harvard University Press, 1999).

Thomas M. Scanlon, What We Owe to Each Other (Cambridge, Massachusetts: Harvard University Press, 1998).

Nicholas B. Smith, 'Sons and fathers in Plato's Euthyphro and Crito', Ancient Philosophy, 34 (2014), 1-13.

Gregory Vlastos, 'Socrates on political obedience and disobedience', The Yale Review 63 (1974), 517-34.

Ellisif Wasmuth, 'Why Socrates' legs didn't run off to Megara: Moral deliberation in Plato's Crito', Phronesis, 65 (2020), 380-412.

Ernst J. Weinrib, 'Obedience to the Law in Plato's Crito', American Fournal of Jurisprudence, 27 (1982) 85-108.

Roslyn Weiss, Socrates Dissatisfied: An Analysis of Plato's Crito, (Maryland: Rowman \& Littlefield, 2001).

Anthony D. Woozley, Law and Obedience: The Arguments of Plato's Crito (London: Duckworth, 1979).

Gary Young, 'Socrates and obedience', Phronesis 19 (1974), 1-29.

HIROSHI OHTANI (h_ohtani@lab.twcu.ac.jp) is Associate Professor of Philosophy at Tokyo Woman's Christian University. His book Wittgenstein Meikakuka no Tetsugaku (Wittgenstein's Philosophical Clarification) (in Fapanese) was published by Seidosha in 2020. 